\title{
The Blurred Boundaries Between Budget Transparency and State Secrecy: a Survey of Three Departments Across 36 Chinese Municipalities
}

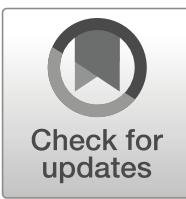

\author{
Longjin Chen ${ }^{1} \cdot$ Junling Zhang ${ }^{2}$
}

Received: 13 April 2020 / Accepted: 6 August 2020 / Published online: 19 August 2020

(C) Springer Nature B.V. 2020

\begin{abstract}
The tension between ensuring open government information and maintaining national security is a widespread problem around the world. This study focuses on the disclosure of budgetary information and its tension with vaguely defined state secrecy requirements in the Chinese context. Through a survey of three government departments that potentially involve state secrets across 36 Chinese municipalities, we find that there exists no consensus on whether to make budgetary information public, even for the same department across different jurisdictions. In addition, departments that chose disclosure vary considerably in the scope and depth of their transparency. Without having the boundaries clarified by law, disclosure by request, as a supplemental behavior to proactive disclosure, can rarely be successful. Our findings suggest that future legislation ought to clarify the legitimate scope of restrictions on budget transparency on the grounds of state secrecy.
\end{abstract}

Keywords Budget transparency $\cdot$ Open government information $\cdot$ National security $\cdot$ State secrets $\cdot$ Secrecy

Junling Zhang

zhang-j109@ hotmail.com

Longjin Chen

chenlongjin@swu.edu.cn

1 Department of Economics \& Center for Economic Research, College of Economics and Management, Southwest University, Chongqing, China

2 School of Public Finance and Taxation Affairs, Southwestern University of Finance and Economics, Chengdu, China 


\section{Introduction}

There is a consistent tension between ensuring open government information and maintaining national security. This tension exists not only in the USA, as seen in responses to the September 11 attacks and the Snowden leaks, but also in other established democracies and developing economies [8, 27]. The main concern of the general public and academics is that national security is too often an excuse to dodge demands for government transparency. Claiming issues of state secrecy, government officials are often reluctant to consider the marginal benefits and costs of transparency versus societal stability and national security. Instead, they tend to adopt a Procrustean approach of one-size-fits-all, which lacks recognition of the "qualified right" to particular government information [25].

Why should the boundaries for determining state secrets be marked clearly and carefully? Steven Aftergood [1] identifies three distinct motivations for government secrecy: (a) "genuine national security secrecy," (b) "bureaucratic secrecy" to avoid blame [30], and (c) "political secrecy" to cover up policy failures. When the boundaries for determining state secrets are blurred, government activity apart from the genuine purpose of national security can become a breeding ground for bureaucracy and corruption and lead to reduced government performance and accountability. When this happens, secrecy is not conducive to societal stability and national security but is harmful instead $[7,25]$. $^{1}$

This study focuses on the disclosure of budgetary data, a particular kind of government information, and its tension with vaguely defined state secrecy requirements in the Chinese context. Budget transparency is an important indicator of a nation's achievements in governance $[2,5,6,12,15,20,28]$. Although China has enjoyed rapid growth and development for four decades, budget transparency remains low at all levels of government $[9,11]$. For example, the average budget transparency rating was $48.26 \%$ for provincial-level governments in 2015 and $49.33 \%$ for municipalities and prefectures in 2017 [22, 23]. Although there are multiple reasons for low transparency, this study focuses on a particular hindrance to the disclosure of government information: the absence of legal clarification of state secrecy requirements and the resulting tension with budget transparency.

Using publicly available Chinese budgetary data, this study was intended to reveal where and how the boundaries between budget transparency and state secrecy requirements are drawn in practice. First, we noted that, while no nationally approved legislation stipulates which government departments involve state secrets, local authorities do not publicize criteria for defining secret-involving departments. Our brief examination of published budgetary documents in jurisdictions at multiple levels

\footnotetext{
${ }^{1}$ A case in point is the National Reconnaissance Office (NRO). As a US Department of Defense agency that develops and operates satellites in secrecy, the NRO long suffered from "failed management, bungled technical assessments, and repeated engineering and testing failures" [21]. Another case is that the US Department of Energy, in the name of national security, would rather compromise unwitting citizens at Hanford in Washington State than alert them to massive radiation from abandoned nuclear facilities [29]. Likewise, the Chinese Ministry of Environmental Protection attempted to use state secrets as a rationale to justify its refusal to address the serious problem of soil contamination [18]. In fact, a lesson learned the hard way during the 2003 outbreak of the severe acute respiratory syndrome (SARS) in China is that blocking information during a state of emergency actually undermines societal stability and imperils domestic and even international security $[4,19]$.
} 
revealed that all information about the State Security Bureau (国家安全局) was missing, indicating that the State Security Bureau is uniformly classified a secret-involving department. Moreover, we noted that the Political and Legal Affairs Commission (政 法委员会), the State Secrecy Commission/Bureau (保密委员会办公室/国家保密局), and the Civil Air Defense Office (人民防空办公室) in many municipalities conceal their budgetary information from the public, pleading state secrecy. We accordingly assumed that these departments possibly involve state secrets.

Second, guided by the Operating Procedures for Publicly Releasing Local Budgets and Final Accounts (地方预决算公开操作规程, the Procedures hereafter), we surveyed budget disclosure practices across the three selected government departments. We found that budget disclosure decisions for a given department differed across municipalities. Among the departments that chose disclosure, there was a great variety across municipalities in the contents and forms of disclosed budgetary documents. Such variations highlight the absence of an unambiguous definition at the national level and the lack of coordination at subnational levels.

Third, because the Regulations of the People's Republic of China on Open Government Information (中华人民共和国政府信息公开条例, the Regulations hereafter) and the Procedures acknowledge “disclosure by request (依申请公开)" as a supplementary channel to "proactive disclosure" (主动公开), we filed a request to the Civil Air Defense Office, seeking budgetary data on the state assets for which they authorized commercial use. Not a single Office provided the information that we sought or gave a convincing explanation why state assets being commercially used should be considered a secret. Moreover, nearly 50\% of the Offices flouted the Regulations and the Procedures by not responding to our request. Our survey results suggest that future legislation ought to clarify the legitimate boundaries between budget transparency and state secrecy. Otherwise, with unchecked discretion, budget disclosure cannot be guaranteed as "comprehensive, authentic, and integrated."

The remainder of this paper is organized as follows. Next, we will outline Chinese legislations concerning both budget transparency and state secrecy and describe the three potentially secret-involving departments selected for the survey. We will present the budget disclosure survey of the three departments across 36 Chinese municipalities in the following section. The survey results will be discussed then, leading to our conclusion with policy implications in the final section.

\section{Institutional Background}

\section{Legislations Toward Budget Transparency}

In place of the earlier Regulations on State Budget Management (国家预算管理条例), the original Budget Law of the People's Republic of China (中华人民共和国预算法) came into effect on January 1, 1995. Throughout this version of the Budget Law, however, there was no reference to “open/openness (公开)" or "transparent/transparency (透明)" in the text. This Budget Law thus provided a set of rules seemingly intended for internal use only. This webpage was not refreshed until the issuance of the Regulations started a new phase on May 1, 2008. According to the Regulations, all governments in mainland China must proactively release financial information such as 
budgetary reports, service charges, and government procurement contracts. This Regulations marked a milestone, by which the Chinese government recognized open government information as a principle of governance for the first time.

Aiming to "enhance the transparency of government work" (Article 1), the Regulations specifies that "administrative departments shall disclose government information promptly and accurately" (Article 6). Government websites are one of the key means to proactively disclose government information (Article 15) such as reports on government budgets and final accounts (Article 10). In addition to legislating proactive disclosure by administrative departments, the Regulations authorizes citizens, legal persons, and other organizations to file requests for obtaining relevant government information (Article 13). Although the principle of transparency was absent from the old Budget Law at the time, the Regulations laid a foundation for further pursuit of budget disclosure.

In 2013, the Communist Party of China (CPC) made a promise to adopt "an allinclusive, standardized, and transparent budget system." In 2014, the original Budget Law was supplemented with stipulations that budgetary reports and final accounts must be made public in a timely manner.

In the new Budget Law effective on January 1, 2015, the pursuit of an "open and transparent budget system" (Article 1) was recognized in statutory law for the first time. According to the new Budget Law, government budgets include general public budgets, budgets for government-managed funds, budgets for state-owned capital operations, and budgets for social insurance funds (Article 5). Moreover, all budgetary documents that have been approved by the People's Congress or reviewed by the Ministry/Department of Finance should be made available to the general public within 20 weekdays (Article 14). Because both the Regulations and the new Budget Law highlighted the general principles of open government information, responsibility for ensuring budget transparency through dayto-day practices fell to the Chinese Ministry of Finance.

In 2016, to facilitate the implementation of the Regulations and the new Budget Law, the Chinese Ministry of Finance issued the Procedures on October 27. This move required subnational governments to follow detailed guidelines on the scope, format, and timeliness of budget disclosures. According to the Procedures, "disclosure is the norm (常态) and nondisclosure shall be handled as exceptions (例外)" (Article 3) and “except for matters involving state secrets, items to be disclosed must be completely disclosed, with the contents being comprehensive, authentic, and integrated" (Article 3).

To fulfill disclosure as "the norm," subnational governments are required to release budgetary information promptly, accurately, and in standard forms (Article 4). Additional language such as "pay attention to actual effects," "respond to societal concerns," and "facilitate public scrutiny" (Article 4) suggests that the Chinese government no longer considers budgetary documents to be private information used exclusively for internal control. Indeed, budget transparency covers more than just budget disclosure and the extent to which additional information can be understood and used by citizens is a powerful indicator of effectiveness $[13,14,26]$. The centerpiece of the Procedures is the provisions of the number of budget tables and the depth of information disclosure (Articles 11-15 and 18-19). In particular, Article 20 puts emphasis on the use of government websites to demonstrate and archive budgetary reports and final accounts.

However, neither the Regulations, the new Budget Law, nor the Procedures ever clarifies which government departments or types of budgetary data involve state secrets 
and which may therefore be sealed, as "exceptions" to "the norm," from public oversight. Because present legislations fail to establish clear boundaries between budget transparency ("the norm") and state secrecy ("exceptions"), both the general public and academics are confused about whether and how much a government department that claims state secrecy requirements should disclose its budget.

\section{Legislations Regarding State Secrecy}

Prior to 1989 when the Interim Regulations on State Secrecy (保守国家机密暂行条例) legislation was repealed, state fiscal plans and state budgetary estimates, documents, and final accounts were considered privileged information (Article 2). Prior to 2004, 1 year after the SARS outbreak, the annual budgetary report prepared by the central government and submitted to the National People's Congress was stamped "State Secrets."

According to the present State Secrecy Law of the People's Republic of China (中华 人民共和国保守国家秘密法), state secrets are “matters that have a vital bearing on state security and national interests and, as specified by legal procedure, are entrusted to a limited number of people for a given period of time" (Article 2). More specifically, state secrets can include privileged information on (1) major policy decisions about state affairs; (2) the building of national defense and the activities of the armed forces; (3) diplomatic activity, foreign affairs, and commitments to the secrecy about foreign countries; (4) the national economy and social development; (5) science and technology; (6) activities to safeguard state security and to investigate criminal offenses; and (7) other matters classified by state secrecy authorities (Article 9). ${ }^{2}$ Given this broad scope of restriction, interpretations of what qualifies as a state secret and, in particular, what government finances should be considered classified information are subjective and vary widely. ${ }^{3}$

The Regulations states that "open government information via administrative departments shall not menace state security, public safety, economic security, and societal stability" (Article 8). As a standard procedure, "prior to disclosure, administrative departments shall review the information to be disclosed in accordance with the State Secrecy Law and any other laws or regulations that may apply" (Article 14). As for the new Budget Law, there is a general provision that budgetary documents and government procurement contracts should not be made public in cases involving state secrets (Article 14). Moreover, the whole Chapter 7 of the Procedures is devoted to handling classified information.

With the catch-all provision in the State Secrecy Law, the general public struggles to understand which government finances constitute state secrets. Unfortunately, this question is answered neither in the Budget Law, in the Regulations, nor in the Procedures, creating confusion about the proper scope and extent of disclosure to which a particular department ought to adhere. This lack of clarity in present legislations is at the root of disputes over the boundaries between budget transparency and

\footnotetext{
2 The first State Secrecy Law took effect on May 1, 1989. The present State Secrecy Law was passed on April 29, 2010, and became effective on October 1, 2010.

${ }^{3}$ In Executive Order 13526 signed by US President Obama, the scope of "national security" is restricted primarily to national defense and foreign affairs. The Order also states that secrecy shall not be exploited to "conceal violations of law, inefficiency, or administrative error." Compared with practices in other countries, the definitions of "national security" and "state secrets" remain broad and vague in China.
} 
state secrecy. The existence of such blurred boundaries is expected to undermine the stipulation that disclosed budgetary information should be made "convenient to find, simple to understand, and open to scrutiny" (Article 4 in the Procedures). In fact, as will be shown later, there are wide variations across jurisdictions in the scope, extent, and format of budget disclosure by departments that claim to deal with state secrets. Such variations are likely because of the lack of clarity from both legislative and administrative branches.

\section{Three Departments That Potentially Involve State Secrets}

To the best of our knowledge, no existing Chinese laws and regulations openly define government departments that work with state secrets. In practice, these decisions are made at each administrative level, by the State Secrecy Commission/Bureau at the same level, and with guidance from one level above. How local authorities make their decisions is classified information and not subject to either proactive disclosure or disclosure by request. For insight, we examined the 2017 budgets published on a number of local-government websites. The State Security Bureau never appeared among the departments that disclose budgetary information, which strongly indicates that, regardless of jurisdictions, the State Secrecy Commission/Bureau uniformly defines the State Security Bureau as a secret-involving department. Moreover, we found that the Political and Legal Affairs Commission, the State Secrecy Commission/Bureau, and the Civil Air Defense Office were likely to disclose fairly limited information about their budgets, all on the grounds of "involving state secrets." For example, the Political and Legal Affairs Commission of Changchun stated in the budgetary report that detailed information on general public-service spending had been concealed to abide by secrecy laws and regulations. Likewise, invoking a notice by the State Civil Air Defense Office, the Civil Air Defense Office of Nanning claimed that defense outlays involved state secrets and thus considered classified information. We thus defined these three departments as potentially involving state secrets.

Under the direction of the CPC Committee and in charge of stability maintenance, the Political and Legal Affairs Commission oversees the People's Procuratorate, the People's Court, the Public Security Bureau, the Judicial Bureau, and the State Security Bureau. The State Secrecy Commission/Bureau is a party-government department responsible for responsibilities such as drafting local regulations and rules concerning state secrecy, defining classification levels of government documents, and supervising the enforcement of the State Secrecy Law. The functions of the Civil Air Defense Office include managing funds, facilities, and supplies for civil air defense, planning and implementing corresponding construction projects, and developing air defense plans and conducting air raid drills.

Because we cannot know, according to any official classification, exactly which departments do involve state secrets, we chose the three above-mentioned departments for our survey, based on their basic functions and their statements on non-disclosure. The present study proceeds with a survey of the three departments across 36 municipalities in mainland China, with the goal of calling attention to the lack of budget transparency under the guise of state secrecy. 


\section{Budget Transparency in the Three Municipal Departments}

Why should due attention be given to budget transparency in departments that claim to involve state secrets? First, despite the announcement that "disclosure is the norm and non-disclosure shall be handled as exceptions," present laws or regulations fail to provide a list of the privileged departments to which full disclosure does not apply. In the absence of clearly defined boundaries, the scope and depth of budget disclosure by given department vary significantly across jurisdictions. One purpose of this study is to demonstrate the need for further legislation to protect both transparency and secrecy. Second, most government units, including those involving state secrets, incur the socalled three public expenses (“三公”经费) from overseas trips, vehicle purchases and uses, and receptions that point to on-duty consumption. Moreover, the Civil Air Defense Office, in particular, manages facilities that generate considerable rental revenues, e.g., underground parking garages and commercial warehouses. Consistently publicizing departmental "three public expenses" and business revenues can help to deter corrupt activity under the guise of state secrecy. Last, this study per se serves as an exercise of the legally protected right to know how much public money is raised and spent. In addition to conducting a survey on proactive budget disclosure, we requested information about business revenues to see whether and how the Civil Air Defense Office would "pay attention to actual effects" and "respond to societal concerns" as stipulated in the Regulations.

Our sample consists of 36 municipalities in mainland China, including four centrally direct-controlled municipalities, 27 capitals of provinces and autonomous regions (including 10 subprovincial municipalities), and five municipalities with subprovincial administrative status. The names of the 36 municipalities are listed in Table 1. Guided by the Procedures effective in 2017, we browsed municipal websites and searched for 2017 budgetary information for the Political and Legal Affairs Commission, the Secrecy Commission/Bureau, and the Civil Air Defense Office, respectively. ${ }^{4}$

\section{Full/Partial Disclosure Versus Non-disclosure}

According to the Procedures, local-government departments other than the Department of Finance should release at least eight budget tables to report (1) the general state of revenues and expenditures, (2) the general state of revenues, (3) the general state of expenditures, (4) the general state of revenues and expenditures through fiscal grants, (5) the general public budget for expenditures, (6) the general public budget for basic expenditures, (7) the general public budget for the "three public expenses," and (8) the budget for governmental-fund expenditures.

Departments that released all eight tables were marked as meeting "full disclosure" requirements. Departments were labeled "partial disclosure," if at least one but no more than seven tables were made public. Table 2 provides a summary of how the three departments disclose their 2017 budget tables across 36 municipalities. The Political and Legal Affairs Commission in most municipalities (23) met the requirement of eight tables, while nine municipalities refused to provide any budgetary information on this department. In stark contrast, most State Secrecy Commission/Bureaus (33) concealed

\footnotetext{
${ }^{4}$ Data released later than June 1, 2017, if any, were not collected and used for the present study.
} 
Table 1 The 36 Chinese municipalities

\begin{tabular}{|c|c|}
\hline $\begin{array}{l}\text { Centrally direct-controlled } \\
\text { municipalities }\end{array}$ & Beijing (北京), Tianjin (天津), Shanghai (上海), and Chongqing (重庆) (4) \\
\hline $\begin{array}{l}\text { Provincial capitals with } \\
\text { subprovincial status }\end{array}$ & $\begin{array}{l}\text { Shenyang (沈阳), Changchun (长春), Harbin (哈尔滨), Nanjing (南京), } \\
\text { Hangzhou (杭州), Jinan (济南), Wuhan (武汉), Guangzhou (广州), Chengdu } \\
\text { (成都), and Xi’an (西安) (10) }\end{array}$ \\
\hline $\begin{array}{l}\text { Provincial or autonomous } \\
\text { region capitals }\end{array}$ & $\begin{array}{l}\text { Shijiazhuang (石家庄), Taiyuan (太原), Hohhot (呼和浩特), Hefei (合肥), } \\
\text { Fuzhou (福州), Nanchang (南昌), Zhengzhou (郑州), Changsha (长沙), } \\
\text { Nanning (南宁), Haikou (海口), Guiyang (贵阳), Kunming (昆明), Lhasa (拉 } \\
\text { 萨), Lanzhou (兰州), Xining (西宁), Yinchuan (银川), and Urumqi (乌鲁木 } \\
\text { 齐) (17) }\end{array}$ \\
\hline $\begin{array}{l}\text { Municipalities with } \\
\text { subprovincial status }\end{array}$ & $\begin{array}{l}\text { Dalian (大连), Ningbo (宁波), Xiamen (厦门), Qingdao (青岛), and Shenzhen } \\
\quad \text { (深圳) (5) }\end{array}$ \\
\hline
\end{tabular}

all budgetary information from the public. Nevertheless, Fuzhou and Guiyang did release all eight tables for their Secrecy Bureaus, while Kunming released half of them.

Table 2 Disclosure of budget tables

\begin{tabular}{|c|c|c|c|}
\hline & $\begin{array}{l}\text { Political and Legal Affairs } \\
\text { Commission (total: } 36 \text { ) }\end{array}$ & $\begin{array}{l}\text { State Secrecy Commission/ } \\
\text { Bureau (total: } 36 \text { ) }\end{array}$ & $\begin{array}{l}\text { Civil Air Defense } \\
\text { Office (total: } 36 \text { ) }\end{array}$ \\
\hline Full disclosure & $\begin{array}{l}\text { Hohhot, Shenyang, } \\
\text { Changchun, Harbin, } \\
\text { Shanghai, Nanjing, } \\
\text { Hangzhou, Ningbo, Hefei, } \\
\text { Fuzhou, Nanchang, Jinan, } \\
\text { Zhengzhou, Wuhan, } \\
\text { Changsha, Shenzhen, } \\
\text { Haikou, Chongqing, } \\
\text { Guiyang, Kunming, } \\
\text { Lhasa, Lanzhou, and } \\
\text { Yinchuan (23/36) }\end{array}$ & Fuzhou and Guiyang $(2 / 36)$ & $\begin{array}{l}\text { Hohhot, Shenyang, Xiamen, } \\
\text { Shenzhen, Haikou, Lhasa, } \\
\text { Lanzhou, Yinchuan, and } \\
\text { Urumqi }(9 / 36)\end{array}$ \\
\hline $\begin{array}{l}\text { Partial } \\
\text { disclosure }\end{array}$ & $\begin{array}{l}\text { Dalian, Qingdao, Nanning, } \\
\text { and Xining }(4 / 36)\end{array}$ & Kunming (1/36) & $\begin{array}{l}\text { Shijiazhuang, Dalian, } \\
\text { Fuzhou, Guangzhou, } \\
\text { Chengdu, and Xi'an } \\
(6 / 36)\end{array}$ \\
\hline Non-disclosure & $\begin{array}{l}\text { Beijing, Tianjin, } \\
\text { Shijiazhuang, Taiyuan, } \\
\text { Xiamen, Guangzhou, } \\
\text { Chengdu, Xi'an, and } \\
\text { Urumqi }(9 / 36)\end{array}$ & $\begin{array}{l}\text { Beijing, Tianjin, } \\
\text { Shijiazhuang, Taiyuan, } \\
\text { Hohhot, Shenyang, Dalian, } \\
\text { Changchun, Harbin, } \\
\text { Shanghai, Nanjing, } \\
\text { Hangzhou, Ningbo, Hefei, } \\
\text { Xiamen, Nanchang, Jinan, } \\
\text { Qingdao, Zhengzhou, } \\
\text { Wuhan, Changsha, } \\
\text { Guangzhou, Shenzhen, } \\
\text { Nanning, Haikou, } \\
\text { Chongqing, Chengdu, } \\
\text { Lhasa, Xi'an, Lanzhou, } \\
\text { Xining, Yinchuan, and } \\
\text { Urumqi (33/36) }\end{array}$ & $\begin{array}{l}\text { Beijing, Tianjin, Taiyuan, } \\
\text { Changchun, Harbin, } \\
\text { Shanghai, Nanjing, } \\
\text { Hangzhou, Ningbo, } \\
\text { Hefei, Nanchang, Jinan, } \\
\text { Qingdao, Zhengzhou, } \\
\text { Wuhan, Changsha, } \\
\text { Nanning, Chongqing, } \\
\text { Guiyang, Kunming, and } \\
\text { Xining }(21 / 36)\end{array}$ \\
\hline
\end{tabular}


Regarding the Civil Air Defense Office, the municipalities of full disclosure and of non-disclosure amounted to nine and 21 , respectively.

Despite differences among municipalities, a given government department should perform similar functions and engage in similar financial activities across jurisdictions. The claim that the same department is deeply involved with state secrets in some municipalities and not at all in others is unconvincing. In fact, however, there were significant variations in budget disclosure by the same department across municipalities. For example, while Hohhot, the capital of a frontier autonomous region, fully disclosed its budgets for the Political and Legal Affairs Commission and for the Civil Air Defense Office, Beijing, the national capital of China, and surrounding Tianjin and Taiyuan, chose to withhold all three departments' budgetary information from public oversight.

Survey results in Table 2 indicate no nationwide consensus on which departments and which outlays should be handled as classified information. Thus, the question of whether to invoke the state-secret privilege is left to local discretion. Where the boundaries between required transparency and necessary secrecy are blurred, stances on both sides of the divide cannot both be justified. Either those who claim the need for state secrecy are concealing information and deviating from the Regulations, the new Budget Law, and the Procedures, or those who are fully disclosing information are potentially harming the public interest and breaking the State Secrecy Law.

\section{Variations in Disclosure}

Within the subgroup of disclosure departments, there were additional variations across municipalities. First, apart from budget tables, the Procedures requires publicizing details on important departmental matters, including (1) basic functions, (2) organizational structure, (3) changes in budgetary revenues and expenditures, (4) arrangements of overhead expenses, (5) government procurement, (6) technical terms, (7) the stock of state-owned assets, (8) performance goals for key projects, and (9) performance evaluations for key projects. Not surprisingly, no single municipal department in the sample shared details on all nine items. As shown in Table 3, the most frequently omitted details concern changes in budgetary revenues and expenditures, the stock of state-owned assets, and performance evaluations for key projects.

Second, according to the new Budget Law, after the approval by the People's Congress, each department's budget should be reviewed by the same-level Department of Finance within 20 weekdays. The Procedures further stipulates that the reviewed budgets should be made public within 20 weekdays. In other words, the general public should have access to all budgets within 40 weekdays after the session. As shown in Table 4, most disclosures take place in the period of 31-40 weekdays. Within the subgroup of disclosure departments, the Political and Legal Affairs Commission of Chongqing and the Civil Air Defense Office of Urumqi failed to meet the time limit.

Third, the Procedures requires disclosed budgetary information to be posted and maintained on government websites. Since 2017, a unified portal for open budgetary information has been added to the website of the Department of Finance. However, this portal was not the exclusive source for budgetary information. For example, the budgets for the Political and Legal Affairs Commission of Chongqing and for the Civil Air Defense Office of Guangzhou were not posted on the website of the Department of 
Table 3 Additional department details made public

\begin{tabular}{llll}
\hline & $\begin{array}{l}\text { Political-Legal } \\
\text { Commission } \\
\text { (total: 27) }\end{array}$ & $\begin{array}{l}\text { State Secrecy } \\
\text { Commission/Bureau } \\
\text { (total: 3) }\end{array}$ & $\begin{array}{l}\text { Civil Air Defense } \\
\text { Office (total: 14) }\end{array}$ \\
\hline Basic functions & $27 / 27$ & $3 / 3$ & $11 / 14$ \\
Organizational structure & $27 / 27$ & $3 / 3$ & $10 / 14$ \\
Changes in budgetary revenues and expenditures & $12 / 27$ & 0 & $5 / 14$ \\
Arrangements of overhead expenses & $19 / 27$ & $1 / 3$ & $5 / 14$ \\
Government procurement & $22 / 27$ & $2 / 3$ & $8 / 14$ \\
Technical terms & $18 / 27$ & $3 / 3$ & $5 / 14$ \\
The stock of state-owned assets & $14 / 27$ & $2 / 3$ & $5 / 14$ \\
Performance goals for key projects & $18 / 27$ & $2 / 3$ & $5 / 14$ \\
Performance evaluations for key projects & $2 / 27$ & 0 & $2 / 14$ \\
\hline
\end{tabular}

Finance but found on their own webpage where general notices and bulletins are posted. Similarly, the State Secrecy Bureau of Guiyang published its budgetary documents under "open management of CPC affairs." 5

Last, let us briefly review some budgetary data on the "three public expenses" and “other expenses (其他支出)." In light of a 2013 promise from the General Office of the State Council, departmental "three public expenses" should gradually reduce, starting from the center to local governments. Notably, among our sample departments that reported changes from last years' figures, the Political and Legal Affairs Commission of Harbin and the Civil Air Defense Offices of Guangzhou, of Chengdu, and of Xi'an in fact budgeted more for their "three public expenses" without sufficient explanations. Furthermore, among the departments that filled out the budget tables as required, "expenditures on other goods and services" and "other transport expenses" appeared to be used strategically to hide detailed information. The worst example presented in Table 5 is Fuzhou. Both the Political and Legal Affairs Commission and the Secrecy Bureau of Fuzhou "completely" disclosed eight budget tables as the Procedures requires. However, their "expenditures on other goods and services" accounted for as much as $100 \%$ of total budgetary spending. In view of black boxes such as "other expenses," the number of disclosed budget tables is not necessarily an informative indicator of budget transparency.

\section{An Attempt to Request Disclosure}

According to the Regulations on the State-Owned Assets for Civil Air Defense (人民防 空国有资产管理规定) issued in 1998, air defense assets may be of a business or nonbusiness use (Article 10). Air defense assets for business use commonly include shopping arcades, warehouses, and basement garages leased under the authorization

\footnotetext{
${ }^{5}$ Previous studies show that website functionality is a strong predictor of government transparency [3]. Meanwhile, the ease with which a user can find necessary information directly affects information disclosure effectiveness $[16,31]$.
} 
Table 4 Timing of budget disclosures

\begin{tabular}{llll}
\hline & $\begin{array}{l}\text { Political and Legal Affairs } \\
\text { Commission (total: 27) }\end{array}$ & $\begin{array}{l}\text { State Secrecy Commission/ } \\
\text { Bureau (total: 3) }\end{array}$ & $\begin{array}{l}\text { Civil Air Defense } \\
\text { Office (total: 15) }\end{array}$ \\
\hline $0-10$ days & $2 / 27$ & 0 & $1 / 15$ \\
$11-20$ days & $4 / 27$ & 0 & $4 / 15$ \\
$21-30$ days & $5 / 27$ & $1 / 3$ & $3 / 15$ \\
$31-40$ days & $15 / 27$ & $2 / 3$ & $6 / 15$ \\
After 40 days & $1 / 27$ & 0 & $1 / 15$ \\
\hline
\end{tabular}

of the Civil Air Defense Office. Without further information, there are no obvious reasons why commercially used air defense assets and their associated lease revenues should be shielded under the state-secret privilege. In fact, the vague wording of "national security" and "state secrets" creates loopholes for bureaucracy and corruption. For example, a Civil Air Defense Officer in Chaoyang, Beijing, pocketed CNY 730,000 lease payments and was sentenced to 8 years in prison plus a CNY 100,000 fine [32].

The Regulations states that academic research, as a “special need (特殊需要)," may be justified in requesting disclosure of certain government information (Article 13). ${ }^{6}$ Because no Civil Air Defense Office in the sample released any information about commercially used air defense assets, we filed a real-name request to the Office in the 36 municipalities. The requested information included the sources, amounts, and proportion of business revenues generated from air defense assets.

To implement our request, we first browsed around government websites and found that 30 of the 36 municipalities provided a webpage for submitting information requests, while three municipalities provided an email address for receiving online requests. For the remaining three municipalities that offered no electronic submission options, we used the tractable Express Mail Service (EMS) by China Post to deliver written requests. All 33 electronic requests were submitted on November 10, 2017, and the three EMS parcels were shipped on November 11, 2017. For the three municipalities whose Civil Air Defense Offices' contact information was not available online, it was necessary to send an inquiry to each municipal General Office first. The three General Offices did respond with the requested contact information.

According to the guidelines on information disclosure by request, an administrative department is expected to review the request upon arrival. If a request is deemed appropriate, access to the requested information should be granted to the requester. If the information is deemed to concern state secrets, a notice to justify the decision of non-disclosure must be issued according to the Regulations (Article 21). To abide by the Regulations, an administrative department should respond to a request for disclosure within 15 weekdays (Article 24). We kept track of the number of days since the

\footnotetext{
${ }^{6}$ In the USA, the Administrative Procedure Act effective in 1946 required the requester to justify his or her "need to know" particular government information. It has been replaced by the "right to know" because of the Freedom of Information Act effective in 1967, which lifts restrictions on the requester's identity and motivations. If disclosure were truly the "norm," the government department that refuses to release information would have to justify its "special need" to do so.
} 
Table 5 Examples of large "other expenses"

\begin{tabular}{llll}
\hline & $\begin{array}{l}\text { Political and Legal } \\
\text { Affairs Commission }\end{array}$ & $\begin{array}{l}\text { State Secrecy } \\
\text { Commission/Bureau }\end{array}$ & $\begin{array}{l}\text { Civil Air Defense } \\
\text { Office }\end{array}$ \\
\hline Expenditures on other goods and services & $\begin{array}{l}\text { Fuzhou (100\%) } \\
\text { Hangzhou (47.96\%) } \\
\text { Guiyang (41.00\%) }\end{array}$ & Fuzhou (100\%) & \\
& Hefei (30.87\%) & & \\
Lanzhou (53.72\%) & Kunming (40.78\%) & Xi'an (56.54\%) \\
Other transport expenses & Harbin (50.09\%) & Guiyang (35.46\%) & Lanzhou (41.10\%) \\
& Kunming (45.16\%) & & \\
Dalian (44.79\%) & & \\
\hline Hefei (39.88\%) & & \\
\hline
\end{tabular}

online submissions were accomplished, the emails were successfully delivered, or the EMS parcels were acknowledged as received. Because of relocation, the EMS parcel to the Office of Chongqing was not signed at the first attempt and was finally delivered on November 21. By December 12, 2017, at least 15 weekdays had passed since the last request letter reached the Office. The outcomes are summarized in Table 6. Twenty of the 36 Civil Air Defense Offices adhered to the Regulations and responded to the request within the time limit. Fifteen responses came by phone call, eight of which were accompanied by an email. Four Offices replied through the online submission system. The request to the Office of Beijing was filed electronically, and the response arrived by registered mail on November 27, 2017.

In their responses, the Offices of Dalian and Shenzhen claimed that they had proactively released all the information appropriate for disclosure and that requested information was unavailable because of either state secrecy or having no corresponding budget. The Offices of Shijiazhuang and Nanjing stated that any information other than that concerning the "three public expenses" had to do with state secrets. The remainder argued that any information disclosure would cause a leakage of state secrets. Taken together, none of the 36 Offices gave a straight answer regarding the sources, amounts, and proportion of business revenues generated from air defense assets.

In addition, seven of the 20 responses did not provide any legal justifications for their decision of non-disclosure. The remaining 13 invoked various government regulations and rules including the Regulations, two notices issued by the Civil Air Defense Office of the State, and a notice by the Civil Air Defense Office of Fujian Province.

Table 6 Outcomes of requesting disclosure

$\begin{array}{ll}\text { Reply within } 15 \text { weekdays with justifications } & \begin{array}{c}\text { Beijing, Hohhot, Dalian, Changchun, Hangzhou, Ningbo, } \\ \text { Hefei, Xiamen, Jinan, Shenzhen, Xi'an, Xining, } \\ \text { and Yinchuan (13/36) }\end{array} \\ & \text { Tianjin, Shijiazhuang, Shenyang, Nanjing, Qingdao, } \\ \text { Geply within } 15 \text { weekdays } & \text { Guangzhou, and Chengdu (7/36) } \\ \text { without justifications } & \text { Taiyuan, Harbin, Shanghai, Fuzhou, Nanchang, Zhengzhou, } \\ \text { No reply } & \text { Wuhan, Changsha, Nanning, Haikou, Chongqing, Guiyang, } \\ & \text { Kunming, Lhasa, Lanzhou, and Urumqi (16/36) }\end{array}$




\section{Discussion}

The general consensus that government information disclosure should be compatible with state secrecy requirements is not under dispute. Yet, the results from our survey of three departments across 36 municipalities suggest that there are no clear boundaries defining what information should be disclosed and what information should remain secret. This situation presents a puzzle for both the general public and academics in contemporary China.

First, no existing laws or regulations in China define which government departments involve state secrets. Under the Chinese unitary system, local governments are normally required to carry out specific matters in accordance with centrally determined standards, especially when sensitive issues are involved. As an exception, however, the procedure to define secret-involving departments is highly decentralized: the discretion is given to the State Secrecy Commission/Bureau at each administrative level. When secrets assume national-level rather than local-level importance, the definition of secret-involving departments should fall under the Central/National Office of the State Secrecy Commission/ Bureau. More importantly, the stipulations regarding departments that involve state secrets and their disclosure of budgetary information ought to be in the form of laws or regulations and enacted by the National People's Congress or the State Council.

Second, the absence of an unambiguous definition at the national level and the lack of coordination at subnational levels lead to the same department in different places developing idiosyncratic definitions of what constitutes secret information. As a result, 27 Political and Legal Affairs Commissions in the sample disclosed budget tables to some extent, while nine disclosed nothing, for example. Furthermore, regarding the departments in the disclosure group, there were considerable variations in the scope and depth of transparency. For example, nine of 15 State Secrecy Bureaus released all eight budget tables and the remaining six fell short. To ensure that "disclosure is the norm and non-disclosure shall be handled as exceptions," the "exceptions" need to be clearly and properly specified.

Third, for government departments that do somewhat involve state secrets, a law or regulation should specify what particular departmental information should be concealed from public scrutiny, so as to honor the goal of budget transparency. It is noteworthy that, according to Article 22 of the Regulations, if a request for disclosure involves information that is inappropriate to release but the inappropriate part is separable, the department should allow the requester to access the permitted part of information. In our view, business revenues generated from air defense assets are “separable (区分处理)" from state secrets and should be open to public scrutiny. The intent of Article 22, however, appears to be undermined by bureaucratic inertia and efforts to avoid hassles or even criminal charges. Because government employees in charge of responding to requests worry about controversy or punishment that could follow disclosure, they favor blanket statements at best and resist justifying why withholding particular information is reasonable and necessary. For these very reasons, the need to clearly delimit the boundaries between required transparency and necessary secrecy is even more important $[10,17]$.

Fourth, without having the boundaries clarified by law, disclosure by request, as a supplemental behavior to proactive disclosure, will rarely be successful. In our study, 16 of 36 Civil Air Defense Offices chose to ignore the Procedures and our request, 
while 20 in fact refused to reveal their business revenues without justifying why business revenues should be considered state secrets.

Finally, there exist discrepancies in information disclosed via different channels. For example, the Civil Air Defense Office of Xi'an insisted in its reply to our request for disclosure that all budgetary information should remain confidential, even while its budget for the "three public expenses" was posted proactively online. Given the confusion over the boundaries between budget transparency and sate secrecy, we are unable to determine which of their contradictory moves is lawful.

\section{Conclusion}

Budgetary documents not only contain information that matters to citizens, but also are an important channel to pursue open government information. This study surveys budget transparency in three government departments that potentially involve state secrets across 36 Chinese municipalities. Using open information on government websites, we examined whether and to what extent the three departments' 2017 budgets were made available to the public. We found that there existed no consensus on whether to make budgetary information public, even for the same department across different jurisdictions. In addition, departments that chose disclosure varied considerably in the scope and depth of their transparency. Despite possibly involving state secrets, some departments released all eight budget tables required by the Procedures, whereas others released no information about their finances. Even the "three public expenses" that, by common sense, are less likely to involve state secrets but more likely to breed corruption, were often deemed classified information. As shown in the survey results, the blurred boundaries between budget transparency and state secrecy create confusion for both government employees and the general public. Without any proper definition by law, even efforts to file requests for information cannot dispel such confusion.

Our findings and discussion have important implications for policy. First, the Regulations on Open Government Information and the Operating Procedures for Publicly Releasing Local Budgets and Final Accounts are apparently subordinate to the State Secrecy Law in terms of legal status. The National People's Congress should consider passing an open government law or merging the two existing legislations into a unified state secrecy and open government law to establish a solid legal foundation for transparent government. ${ }^{7}$ Second, present laws and regulations need to be amended to narrowly define vague terms in use such as "state secrets" and "government departments involving state secrets" and to enable itemization of information as (in)appropriate for disclosure. Third, even for departments that involve state secrets, budgetary information about the "three public expenses," business revenues earned through common market transactions, and any other financial arrangements less likely to involve state secrets but more likely to breed corruption should be open to public oversight. ${ }^{8}$

\footnotetext{
${ }_{7}$ Evidence from 93 countries suggests that legislative oversight helps to enhance budget transparency [24]. Thus, strengthening the oversight of the legislature, e.g., the Budgetary Affairs Commission under the Standing Committee of the People's Congress, is fundamental to promoting budget disclosure in China.

${ }^{8}$ The Chinese Ministry of Foreign Affairs used to plead state secrecy and conceal their "three public expenses" from public oversight. Yet since 2004, their disclosure of such budgetary data has never been suspended for the reason of divulging a secret.
} 
This study contributes to the existing literature in several ways. First, how the Chinese government defines secret-involving departments is unclear in the existing literature. This study presents tentative answers with survey evidence. Second, this study focuses in particular on the budget disclosure of three departments that potentially involve state secrets, highlighting a hurdle for budget transparency because of vaguely defined secrecy. Third, the new Budget Law and the Procedures are a milestone for budget disclosure in China. Note that 2017 was the first year in which government departments were required by the Procedures to release additional budget tables. Closely following ongoing fiscal reforms in China, this study provides timely insight into the actual implementation of the Procedures.

Nevertheless, this study is limited in its ability to explain the reasons for the differences in secrecy-related responses across municipalities. It can offer no insight about political, economic, or geographic factors that might contribute to inter-municipal variations in budget disclosure. In fact, our interviews with staff members in the People's Congress and in the Department of Finance suggested that they were either not well informed about the work of the State Secrecy Commission/Bureau or unwilling or unable to share more key information. These limitations may be addressed in future research efforts.

Acknowledgments We are grateful to Yu Zhou, Sha Yu, Muhua Lin, Chaoying Lu, Hong Yang, Tongyan He, Maolin Zhou, Rong Hu, Hong Jiang, Xiaolin Zhou, Xiandi Xie, Jianjun Li, Haosheng Zheng, Nan Li, and the anonymous reviewers for their valuable comments and assistance. Any remaining errors are ours.

Funding Information National Social Science Foundation of China (18XGL013 and 17BGL264)

\section{References}

1. Aftergood, S. (2009). Reducing Government Secrecy: Finding What Works. Yale Law and Policy Review 27, 399-416.

2. Alt, J. E., \& Lassen, D. D. (2006). Fiscal Transparency, Political Parties, and Debt in OECD Countries. European Economic Review 50, 1403-1439.

3. Armstrong, C. L. (2011). Providing a Clearer View: An Examination of Transparency on Local Government Websites. Government Information Quarterly 28, 11-16.

4. Baekkeskov, E., \& Rubin, O. (2017). Information Dilemmas and Blame-Avoidance Strategies: From Secrecy to Lightning Rods in Chinese Health Crises. Governance 30, 425-443.

5. Bastida, F., \& Benito, B. (2007). Central Government Budget Practices and Transparency. Public Administration 85, 667-716.

6. Benito, B., \& Bastida, F. (2009). Budget Transparency, Fiscal Performance, and Political Turnout: An International Approach. Public Administration Review 69, 403-417.

7. Blanton, T. S. (2003). National Security and Open Government in the United States: Beyond the Balancing Test. In Campbell Public Affairs Institute, National Security and Open Government: Striking the Right Balance. Syracuse, NY: Campbell Public Affairs Institute, 33-73.

8. Campbell Public Affairs Institute (2003). National Security and Open Government: Striking the Right Balance. Syracuse, NY: Campbell Public Affairs Institute.

9. Chen, L., Zhou, X., \& Feng, L. (2015). Fiscal Transparency and Budgeting Reform: A Survey of County-Level Governments in Sichuan Province. Journal of the Central University of Finance and Economics, 2015/09: 10-16 (in Chinese).

10. Choi, J. M. (2018). Factors Influencing Public Officials' Responses to Requests for Information Disclosure. Government Information Quarterly 35, 30-42.

11. Deng, S., Peng, J., \& Wang, C. (2013). Fiscal Transparency at the Chinese Provincial Level. Public Administration 91, 947-963. 
12. Ellis, C. J., \& Fender, J. (2006). Corruption and Transparency in a Growth Model. International Tax and Public Finance 13, 115-150.

13. Fung, A., Weil, D., Graham, M., \& Fagotto, E. (2004). The Political Economy of Transparency: What Makes Disclosure Policies Effective? Occasional Paper 03-04, Ash Institute for Democracy and Innovation \& Kennedy School of Government, Harvard University.

14. Ginsberg, W., Carey, M. P., Halchin, L. E., \& Keegan, N. (2012). Government Transparency and Secrecy: An Examination of Meaning and Its Use in the Executive Branch. Congressional Research Service Report R42817.

15. Hameed, F. (2005). Fiscal Transparency and Economic Outcomes. IMF Working Paper 05/225.

16. Henninger, M. (2017). Government Information: Literacies, Behaviours and Practices. Government Information Quarterly 34, 8-15.

17. Hood, C. (2007). What Happens When Transparency Meets Blame-Avoidance? Public Management Review 9, 191-210.

18. Larson, C. (2014). China Gets Serious about Its Pollutant-Laden Soil. Science, 343, 1415-1416.

19. Lawson, J., \& Xu, F. (2007). SARS in Canada and China: Two Approaches to Emergency Health Policy. Governance, 20, 209-232.

20. Milesi-Ferretti, G. M. (2004). Good, Bad or Ugly? On the Effects of Fiscal Rules with Creative Accounting. Journal of Public Economics 88, 377-394.

21. Pasternak, D. (2003). Lack of Intelligence. U.S. News \& World Report, 135 (4), 35-40.

22. Research Center for Public Economics, Finance, and Governance in the School of Public Policy and Management at Tsinghua University (2017). The 2017 Report on Fiscal Transparency in Chinese Municipalities, Prefectures, and Cities. School of Public Policy and Management at Tsinghua University, China (in Chinese).

23. Research Center for Public Policy at Shanghai University of Finance and Economics (2017). The 2017 Annual Report on China's Fiscal Transparency. Shanghai: Shanghai University of Finance and Economics Press (in Chinese).

24. Ríos, A.-M., Bastida, F., \& Benito, B. (2016). Budget Transparency and Legislative Budgetary Oversight: An International Approach. American Review of Public Administration 46, 546-568.

25. Roberts, A. (2004). National Security and Open Government. Georgetown Public Policy Review 9, 6985.

26. Rosenthal, E. (2012). I Disclose ... Nothing: The Hard Truths about Disclosure. New York Times, January 22, 2012.

27. Sagar, R. (2013). Secrets and Leaks: The Dilemma of State Secrecy. Princeton, NJ: Princeton University Press.

28. Seiferling, M., \& Tareq, S. (2015). Fiscal Transparency and the Performance of Government Financial Assets. IMF Working Paper 15/9.

29. Steele, K. D. (1988). Hanford's Bitter Legacy. Bulletin of the Atomic Scientists 44, 17-23.

30. Weaver, R. K. (1986). The Politics of Blame Avoidance. Journal of Public Policy 6, 371-398.

31. Yavuz, N., \& Welch, E. W. (2014). Factors Affecting Openness of Local Government Websites: Examining the Differences across Planning, Finance and Police Departments. Government Information Quarterly 31, 574-583.

32. Zhang, B. (2011). Civil Air Defense Officer Pocketed CNY 730 Thousand in Nine Years from Leased Facilities, Sentenced to Eight Years in Prison and Fined CNY 100 Thousand as First-Trial Decision. Legal Evening News, September 12, 2011 (in Chinese).

Publisher's Note Springer Nature remains neutral with regard to jurisdictional claims in published maps and institutional affiliations. 